Prepared in cooperation with the U.S. Fish and Wildlife Service

\title{
Movement of Bull Trout in the Upper Jarbidge River Watershed, Idaho and Nevada, 2008-09-A Supplement to Open-File Report 2010-1033
}

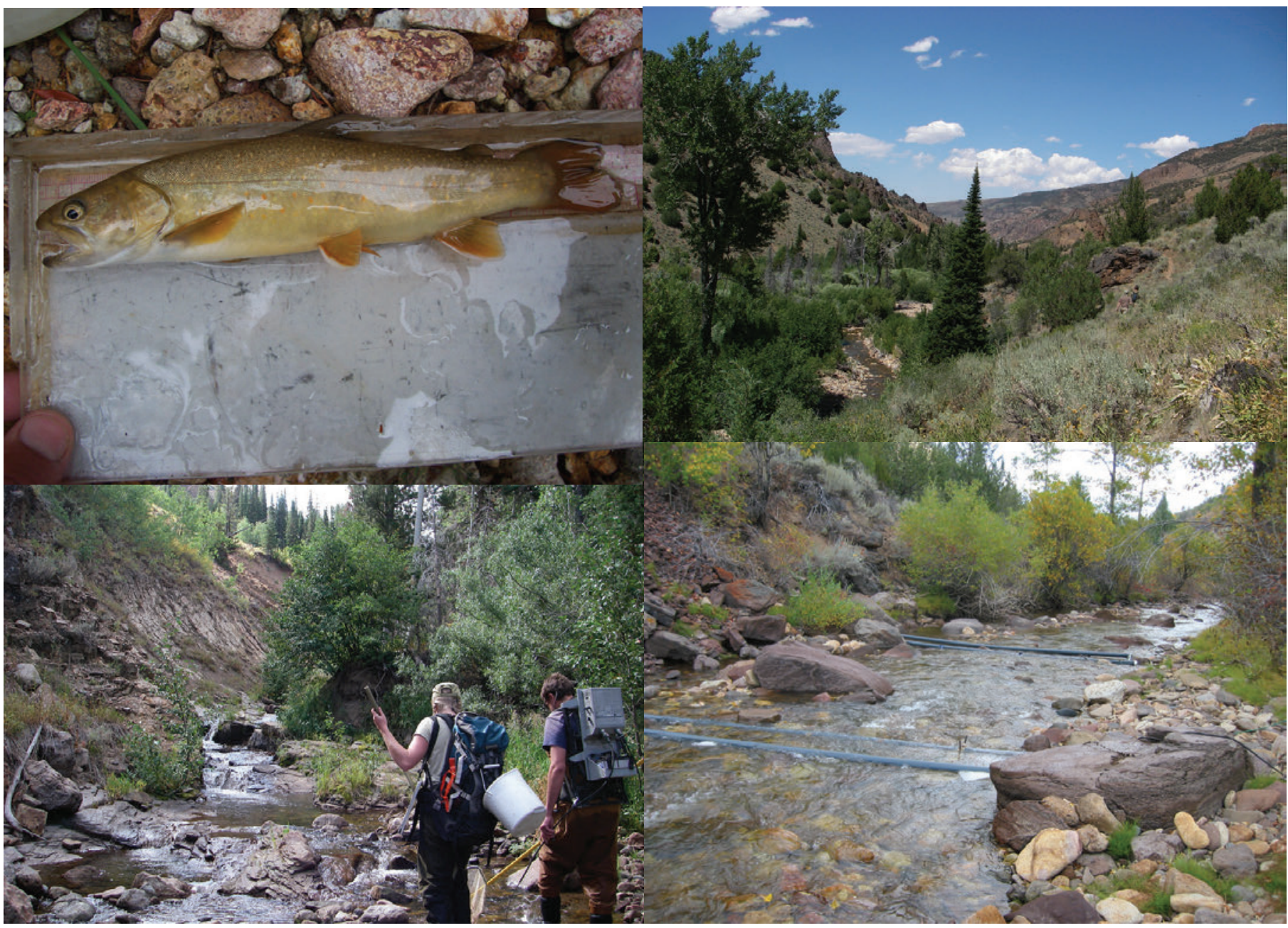

Open-File Report 2011-1090 


\section{Cover photographs:}

Top row (from left to right):

Bull trout, Jarbidge, Nevada. Photograph by Brady Allen, USGS, WFRC Columbia River Research Laboratory.

East Fork Jarbidge River, Jarbidge, Nevada. Photograph by Brady Allen, USGS, WFRC Columbia River Research Laboratory.

Bottom row (from left to right):

Chris Dixon and Dawn Hunt electrofishing in Jack Creek, Jarbidge, Nevada. Photograph by Brady Allen, USGS, WFRC Columbia River Research Laboratory.

PIT-tag Interrogation System in West Fork Jarbidge River, Jarbidge, Nevada. Photograph by Brady Allen, USGS, WFRC Columbia River Research Laboratory. 


\section{Movement of Bull Trout in the Upper Jarbidge River Watershed, Idaho and Nevada, 2008-09-A Supplement to Open-File Report 2010-1033}

By Carrie S. Munz, M. Brady Allen, and Patrick J. Connolly

Prepared in cooperation with the U.S. Fish and Wildlife Service

Open-File Report 2011-1090

U.S. Department of the Interior, U.S. Geological Survey 


\section{U.S. Department of the Interior \\ KEN SALAZAR, Secretary}

\section{U.S. Geological Survey \\ Marcia K. McNutt, Director}

U.S. Geological Survey, Reston, Virginia: 2011 For more information on the USGS-the Federal source for science about the Earth, its
natural and living resources, natural hazards, and the environment, visit http://www.usgs.gov
or call 1-888-ASK-USGS.

For an overview of USGS information products, including maps, imagery, and publications, visit http://www.usgs.gov/pubprod

To order this and other USGS information products, visit http://store.usgs.gov

Any use of trade, product, or firm names is for descriptive purposes only and does not imply endorsement by the U.S. Government.

Although this report is in the public domain, permission must be secured from the individual copyright owners to reproduce any copyrighted material contained within this report.

Suggested citation:

Munz, C.S., Allen, M.B., and Connolly, P.J., 2011, Movement of bull trout in the upper Jarbidge River watershed, Idaho and Nevada, 2008-09-A supplement to Open-File Report 2010-1033: U.S. Geological Survey Open-File Report 2011-1090, 12 p. 


\section{Contents}

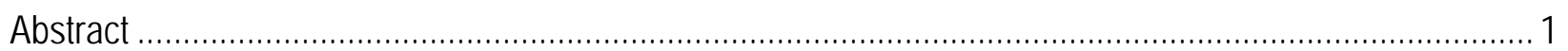

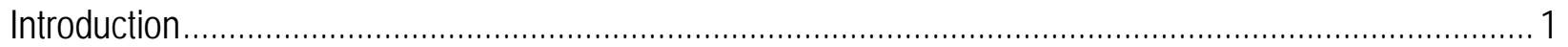

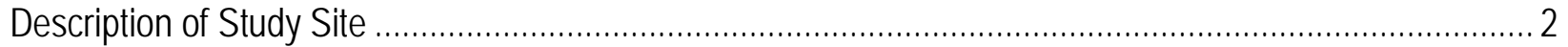

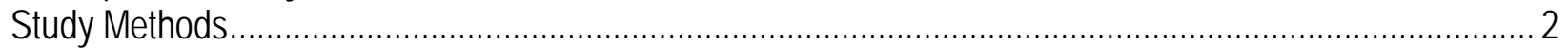

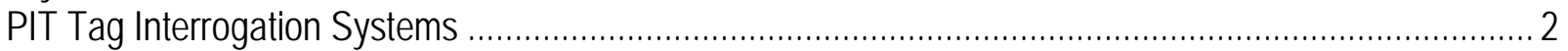

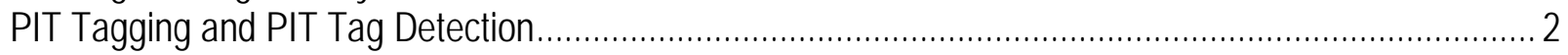

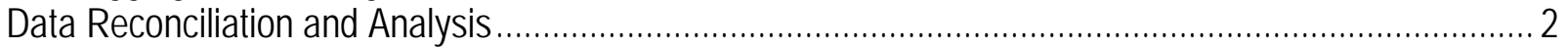

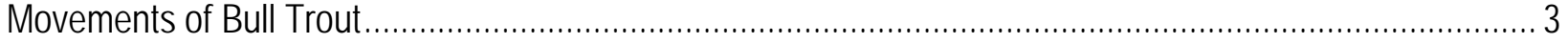

Discussion of Bull Trout Movements......................................................................................... 4

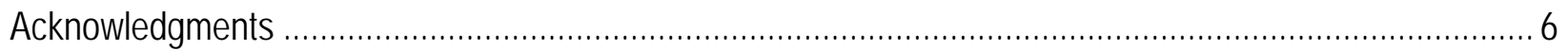

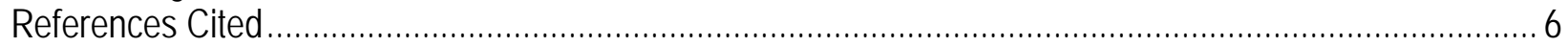

\section{Figures}

Figure 1. Map of the West and East Forks of the Jarbidge River, Idaho and Nevada, with the locations of reported fish passage barriers and passive integrated transponder (PIT) tag interrogation systems

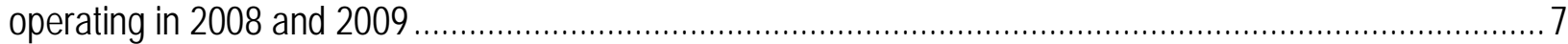

Figure 2. Flow, water temperature, and direction of PIT-tagged bull trout movements detected at PIT tag interrogation sites (PTISs) in East Fork Jarbidge River (EFJ, rkm 4.1), West Fork Jarbidge and Pine Creek confluence (rkm 26), Jack Creek (rkm 0.1), West Fork Jarbidge River (WFJ, rkm 15), and the Forks (rkm $0.1)$, Idaho and Nevada, 2008

Figure 3. Flow, water temperature, and direction of PIT-tagged bull trout movements detected at PIT tag interrogation sites (PTISs) in Dave Creek (rkm 0.4), East Fork Jarbidge River (EFJ, rkm 4.1), West Fork Jarbidge and Pine Creek confluence (rkm 26), Jack Creek (rkm 0.1), West Fork Jarbidge River (WFJ, rkm 15), and the Forks (rkm 0.1), Idaho and Nevada, 2009

\section{Tables}

Table 1. Number of PIT-tagged bull trout detected by tagging location, Idaho and Nevada, 2008-09.........10 Table 2. Total number of PIT-tagged bull trout detected by month in the Jarbidge River watershed, Idaho and Nevada, 2008

Table 3. Total number of PIT-tagged bull trout detected by month in the Jarbidge River watershed, Idaho and Nevada, 2009 


\section{Conversion Factors}

\begin{tabular}{lll}
\hline \multicolumn{1}{c}{ Multiply } & \multicolumn{1}{c}{ By } & \multicolumn{1}{c}{ To obtain } \\
\hline millimeter $(\mathrm{mm})$ & 0.03937 & inch (in.) \\
meter $(\mathrm{m})$ & 3.281 & foot (ft) \\
kilometer $(\mathrm{km})$ & 0.6214 & mile (mi) \\
square kilometer $\left(\mathrm{km}^{2}\right)$ & 0.3861 & square mile (mi $\left.{ }^{2}\right)$ \\
gram (g) & 0.03527 & ounce, avoirdupois (oz) \\
\hline
\end{tabular}

Temperature in degrees Celsius $\left({ }^{\circ} \mathrm{C}\right)$ may be converted to degrees Fahrenheit $\left({ }^{\circ} \mathrm{F}\right)$ as follows: ${ }^{\circ} \mathrm{F}=\left(1.8 \times{ }^{\circ} \mathrm{C}\right)+32$. 


\title{
Movement of Bull Trout in the Upper Jarbidge River Watershed, Idaho and Nevada, 2008-09-A Supplement to Open-File Report 2010-1033
}

By Carrie S. Munz, M. Brady Allen, and Patrick J. Connolly

\begin{abstract}
We monitored bull trout (Salvelinus confluentus) in 2008 and 2009 as a continuation of our work in 2006 and 2007, which involved the tagging of 1,536 bull trout with passive integrated transponder (PIT) tags in the East Fork Jarbidge River and West Fork Jarbidge River and their tributaries in northeastern Nevada and southern Idaho. We installed PIT tag interrogation systems (PTISs) at established locations soon after ice-out, and maintained the PTISs in order to collect information on bull trout movements through December of each year. We observed a marked increase of movement in 2008 and 2009. Bull trout tagged in the uppermost portions of the East Fork Jarbidge River at altitudes greater than 2,100 meters moved to the confluence of the East Fork Jarbidge River and West Fork Jarbidge River in summer and autumn. Ten bull trout tagged upstream of the confluence of Pine Creek and the West Fork Jarbidge River moved downstream and then upstream in the East Fork Jarbidge River, and then past the PTIS at Murphy Hot Springs (river kilometer [rkm] 4.1). Two of these fish ascended Dave Creek, a tributary of the East Fork Jarbidge River, past the PTIS at rkm 0.4. One bull trout that was tagged at rkm 11 in Dave Creek on June 28, 2007 moved downstream to the confluence of the East Fork Jarbidge River and West Fork Jarbidge River (rkm 0) on July 28, 2007, and it was then detected in the West Fork Jarbidge River moving past our PTIS at rkm 15 on May 4, 2008. Combined, the extent and types of bull trout movements observed indicated that the primarily age- 1 and age- 2 bull trout that we tagged in 2006 and 2007 showed increased movement with age and evidence of a substantial amount of fluvial life history. The movements suggest strong connectivity between spawning areas and downstream mainstem areas, as well as between the East Fork Jarbidge River and West Fork Jarbidge River.
\end{abstract}

\section{Introduction}

In 2008 and 2009, personnel from the U.S. Geological Survey’s (USGS) Columbia River Research Laboratory, in cooperation with the U.S. Fish and Wildlife Service (USFWS), continued to obtain information on movement of bull trout (Salvelinus confluentus) previously implanted with passive integrated transponder (PIT) tags in the upper Jarbidge River watershed in 2006-07. The information is intended to assist managers in making informed decisions regarding bull trout recovery. This report summarizes study findings from 2008 and 2009, and serves as a supplement to the report by Allen and others (2010) that covered findings from our 2006-07 efforts. 


\section{Description of Study Site}

The East Fork Jarbidge River and West Fork Jarbidge River flow northward for about 36 and $32 \mathrm{~km}$ before merging about $6.4 \mathrm{~km}$ downstream of the Idaho-Nevada border. This confluence of the forks was the downstream extent of our study area, and what we considered to be river kilometer (rkm) zero (fig. 1). The mainstem Jarbidge River continues downstream another $45 \mathrm{~km}$ northwest and eventually flows into the Bruneau River in Idaho. Runoff follows the natural hydrograph, with snowmelt causing high spring and early summer flows that diminish to base low flow in the late summer, with some increase in flow during autumn and winter. The only streamflow-gaging station in the watershed was within our study area at rkm 19.2 on the West Fork Jarbidge River downstream of Jarbidge, Nevada (USGS Station No. 13162225). Temperature data were collected by the Bureau of Land Management and Nevada Department of Wildlife. For a more detailed description of the Jarbidge River watershed, see Allen and others (2010).

\section{Study Methods}

\section{PIT Tag Interrogation Systems}

In 2008 and 2009, we continued operation of six PIT tag interrogation systems (PTISs) in the Jarbidge River watershed (fig. 1). On March 26, 2008, we installed instream PTISs at six previously established locations (for a detailed description of locations and antenna configuration, see Allen and others, 2010). In the West Fork Jarbidge River, we had antennas at the confluence of Pine Creek and West Fork Jarbidge River (WFP), at the mouth of Jack Creek (JAC), and in the West Fork Jarbidge River (WFJ), about $2.4 \mathrm{~km}$ downstream of the Jack Creek confluence. In the East Fork Jarbidge River, we had a PTIS at rkm 4.1 of the mainstem at Murphy Hot Springs (EFJ) and another at rkm 0.4 in Dave Creek (DAV). We also operated a PTIS at the confluence of the East Fork Jarbidge River and West Fork Jarbidge River (the Forks; rkm 0 for each fork). Data from the PTISs were downloaded and the batteries were changed once a week from March through December 2008, after which the equipment was removed for the winter. In 2009, the six PTISs were reinstalled. All antennas and other PTIS equipment were removed from all sites on December 2, 2009.

\section{PIT Tagging and PIT Tag Detection}

In 2008 and 2009, bull trout were detected downstream of several sites where bull trout were tagged in 2006 and 2007. All PIT-tagged fish detected during 2008-09 were from the 1,536 bull trout that we tagged in 2006 and 2007. We did not PIT tag bull trout in 2008-09. Locations of electro-fishing surveys and the number of bull trout tagged in each stream are described in Allen and others (2010).

\section{Data Reconciliation and Analysis}

We merged interrogation data with tagging data and assessed direction of bull trout movements where possible. Interrogation data were handled as described in Allen and others (2010). As shown in figures 2 and 3, movement events detected at a PTIS were assessed as a fish 
moving upstream, downstream, or in an unknown direction. We were not able to determine direction of movement past the single antenna DAV and JAC PTISs, unless there was a subsequent detection at another PTIS soon after.

\section{Movements of Bull Trout}

In 2006 and 2007, we tagged 1,536 bull trout in the East Fork and West Fork Jarbidge River and their tributaries. During the 257 days that the six PTISs were operated in 2008 (March 26-December 8), we detected movement of 52 individual bull trout, including 15 fish that also were detected in 2007. During the 239 days that the six PTISs were operated in 2009 (April 7December 2), we detected movement of 37 individual bull trout, including six fish that also were detected in 2008, three fish detected in 2008 and 2007, and one fish detected in 2007. We did not detect large-scale movement from any of the fish tagged in the upper tributaries of the East Fork Jarbidge River (Cougar, Fall, and Slide Creeks). However, only 53 bull trout were tagged in those streams, and the closest PTIS was more than $21 \mathrm{rkm}$ downstream at Murphy Hot Springs (Allen and others, 2010). All PTISs operated more or less continuously with the exception of the WFP PTIS, which malfunctioned on June 30, 2009, and was not replaced or repaired. Operating the PTISs in 2008 and 2009 more than doubled the number of individual bull trout detected previously, from a total of 49 in 2006 and 2007 (Allen and others, 2010) to a combined total of 113 over the duration of the study.

Bull trout movements demonstrated high connectivity within and between the East Fork and West Fork Jarbidge River subbasins. For example, 11 of 13 (85 percent) bull trout detected at the EFJ PTIS were tagged in the West Fork Jarbidge River or its tributaries. Eighteen bull trout tagged in Pine Creek entered Jack Creek past the PTIS at rkm 0.1 in July and August 2009 before continuing downstream and being detected at the West Fork Jarbidge River PTISs (table 1). The two bull trout detected in Dave Creek were tagged at altitudes greater than 2,200 $\mathrm{m}$ in Pine Creek, a tributary of the West Fork Jarbidge River. A bull trout tagged in Dave Creek (at about 2,200 m altitude) in June 2007 was detected at the Forks PTISs in July 2007 and the WFJ PTIS in May 2008. Two bull trout tagged in the East Fork Jarbidge River in the uppermost survey locations in 2007 (both at altitudes greater than 2,200 m) moved past the EFJ PTIS (31 rkm downstream), one of which passed by the PTISs at the Forks (another $4.0 \mathrm{rkm}$ downstream). All these fish traveled a minimum of $35 \mathrm{~km}$, and some as much as $40 \mathrm{~km}$ (upper Pine Creek to DAV PTIS).

Several bull trout exhibited extensive migrations within the Jarbidge River watershed. Some of the more extensive migrations observed include:

- A bull trout tagged in Pine Creek (2,240 m altitude) in August 2007 was detected at WFP PTIS in October 2008 (a distance of about $3.5 \mathrm{~km}$ ). In 2009, the same fish was detected moving downstream in the West Fork Jarbidge River at the Forks PTIS and then up the East Fork Jarbidge River at the Forks PTIS on July 16, 2009. It was then detected at the EFJ PTIS on July 18, 2009, and the DAV PTIS on July 21, 2009. The same fish was again detected at the DAV PTIS on September 3, 2009, back at the EFJ PTIS on September 12, 2009, and the Forks PTIS on September 13, 2009.

- Another bull trout tagged in Pine Creek (2,318 m altitude) in August 2007 was detected at WFP PTIS on August 6, 2008. It was detected in Jack Creek on August 10, 2008, and then downstream at the WFJ PTIS on August 11, 2008. The following year, it was detected at the Forks PTIS on September 10, 2009, detected 3 days later at the EFJ PTIS from September 13-23, 2009, and then back at the Forks in 1 day. 
- A bull trout, tagged in Jack Creek in August 2007, left Jack Creek on August 10, 2008, and was detected at the WFJ PTIS on the same day. In 2009, it was detected at the Forks and the EFJ PTISs in July, and went back to the Forks PTIS in September 2009.

- Thirty-nine of the 405 bull trout tagged in Pine Creek at the West Fork Jarbidge River were detected at one of the PTISs. Of those, seven were detected at the EFJ PTIS (table 1). Each of these bull trout traveled at least $30 \mathrm{rkm}$, indicating high potential for interaction among sub-populations.

Most bull trout movements occurred in late summer and early autumn, coincident with decreasing flows and increasing water temperatures (fig. 2). Bull trout were detected moving into Jack Creek in July and August. Jack Creek could provide thermal refuge during July and August, as the water temperature is much lower in Jack Creek than in the West Fork Jarbidge River (fig. 3). Most bull trout detections at the Forks PTISs were in August through October when flow was lowest in the West Fork Jarbidge River. In September and October, bull trout were moving mostly downstream (figs. 3 and 4, tables 2 and 3). Bull trout movements were not detected in November and December in 2008 and 2009.

Bull trout moved into the tributaries during mid-summer, which corresponds to observed spawning time in the Jarbidge River watershed (Allen and others, 2010). In 2008, 28 of the 29 bull trout detected in Jack Creek were during July and August. In 2009, 21 of the 24 bull trout detected in Jack Creek were during July and August. In 2008, 54 of the 71 bull trout detected at Pine Creek were during June, July, and August. In 2009, three of the four bull trout detected in Dave Creek were during July and August. However, the direction of movement was largely unknown, and not necessarily related to spawning (table 1). The PTIS in Pine Creek was nonoperational after July 1, 2009.

\section{Discussion of Bull Trout Movements}

Bull trout that were PIT tagged in 2006 and 2007 exhibited movements in 2008 and 2009 that demonstrated high connectivity between the East Fork and West Fork of the Jarbidge River. Bull trout that were tagged in the uppermost portions of the fish distribution in Pine Creek and the West Fork and East Fork Jarbidge Rivers were detected at the confluence of the forks. Some bull trout were detected as much as $40 \mathrm{rkm}$ from their tagging location. There was less evidence of movement in the spring, particularly in 2009, but this may be due, in part, to a reduction in PIT tag detection efficiency resulting from higher streamflow.

Bull trout tagged in the uppermost portions of their distribution, at altitudes greater than 2,200 m, exhibited movement to the confluence of the East Fork Jarbidge River and West Fork Jarbidge River in the summer and autumn. Pine Creek and the West Fork Jarbidge River upstream of the mouth of Pine Creek were a large source for migratory bull trout, including bull trout that were subsequently detected in the East Fork Jarbidge River as far upstream as Murphy Hot Springs (rkm 4.1). Results of the U.S. Fish and Wildlife Service's genetic analysis (DeHaan and Godfrey, 2009) showed that many individuals collected in other tributaries originated from Pine Creek or the West Fork Jarbidge River further suggesting that it is a source of migratory bull trout. Two fish tagged in Pine Creek were detected in Dave Creek, a tributary of the East Fork Jarbidge River. One bull trout tagged in Dave Creek migrated to the confluence of the East Fork and West Fork, and was subsequently detected at the West Fork Jarbidge River PTIS at rkm 15. High connectivity among tributaries in the Jarbidge River system also was evident in the genetic analysis by DeHaan and Godfrey (2009). Ten of the eighteen fish collected for genetic analysis in East Fork Jarbidge River or its tributaries originated in the West Fork Jarbidge River 
(DeHaan and Godfrey, 2009). Combined, these movements suggest a high degree of connectivity between the East Fork and West Fork of the Jarbidge River, as well as potential interactions among the local populations.

In the Jarbidge River watershed, we found evidence of a fluvial life history, and possibly a resident life history. Many PIT-tagged bull trout either did not move far enough from their tagging locations, or did not live long enough to be detected at any of the PIT tag interrogation systems (PTISs). It also is possible that some bull trout destined to be fluvial had not showed this movement behavior before the PTISs were removed. However, some of these fish could have moved without detection, and the distance between the tagging locations and the PTISs was quite far in some areas. Some PIT-tagged bull trout were only detected at the PTIS nearest to their tagging locations. For example, a bull trout tagged in July 2006 in the West Fork Jarbidge River was detected at the WFP antennas multiple times from October 2007 through June 2009, but at no other PTIS, indicating high site fidelity. In a genetic analysis, DeHaan and Godfrey (2009) found that each tributary contained a genetically distinct spawning population, so although there is evidence of migration, most fish appear to be returning to their native streams to spawn, with little indication of gene flow between the East Fork and West Fork of the Jarbidge River. Bull trout populations that demonstrate multiple life history strategies, such as resident and migratory, are more likely to persist with habitat disturbance and changing environmental conditions than those with limited life history diversity (Homel and Budy, 2008).

An increase in movement was evident during 2008-09 relative to 2006-07. Because there was no PIT tagging in 2008-09, we may have seen an age-related increase in movement due to the maturing of previously age- 1 and age- 2 fish that we tagged in 2006-07. Other researchers have found that bull trout tend to leave their natal streams at age 2 or 3 years (Mogen and Kaeding, 2005). A similar pattern appears to hold for bull trout of the East Fork and West Fork of the Jarbidge River.

To enhance the understanding of the bull trout populations in the Jarbidge River watershed, we believe there is an additional opportunity to track existing PIT-tagged fish through time. Young PIT-tagged fish appeared to be expressing an increased degree of movement as they matured. In 2006 and 2007, few migration patterns were evident, but as the bull trout aged, they began using larger streams. Of the 23 bull trout that were tagged in the West Fork Jarbidge River and detected at the Forks PTIS, only 2 were detected again at any PTIS. In the East Fork Jarbidge, one of two bull trout was not detected again after being detected at the Forks. This could indicate that bull trout are residing downstream of the Forks, or that they experience high mortality if they venture too far downstream. However, the PTISs detection efficiencies were likely low and variable and no PTISs were operating over the winter, meaning that some bull trout movements likely were not detected. Continued monitoring could help understand spawning-related movement, age-related habitat use, and mortality risks of movement behavior.

In addition to the recommendations offered by Allen and others (2010), we believe that the continued operation of the PTISs could yield valuable information for future research. We suggest that there is much to be learned by continued PIT tagging of age- 1 and older bull trout in primary rearing areas (Pine, Jack, and Dave Creeks, as well as the upper portions of the East Fork and West Fork) in conjunction with continuous, seasonal, operation of PTISs at the key locations where they were placed during this study. We had limited coverage to detect movement in the upper East Fork Jarbidge River because of the remoteness of the upper watershed. Emerging PIT tag technology may soon make it feasible to install PTISs in these remote areas. 


\section{Acknowledgments}

We want to acknowledge all members of the Bull Trout Recovery Team, especially Selena Werdon and Allen Taylor of the U.S. Fish and Wildlife Service, for their involvement, interaction, and funding support. We thank Ian Jezorek, Jessica Fischer, Kyle Martens, Liz Copeland, Chris Dixon, Joe Mullen, Anita Lahey, and Brien Rose of the Columbia River Research Laboratory for working tireless hours in the field. We would like to thank the Bureau of Land Management's Richard Bupp in particular for doing an excellent job of maintaining, troubleshooting, and repairing the PTISs during 2009. He was instrumental in ensuring continuous operation of the PTISs during that period. We thank Kate Forster and Daniel Armichardy from the Bureau of Land Management in Twin Falls and Gary Johnson of Nevada Department of Wildlife for providing water temperature data. We also thank the personnel at the U.S. Forest Service's Wells District Ranger Station for use of the Mahoney Guard Station for housing and equipment storage. Krinn and Chuck McCoy of the Tshawhawbitts Bed and Breakfast were gracious hosts of the field crew and provided helpful information on the area.

\section{References Cited}

Allen, M.B., Connolly, P.J., Mesa, M.G., Charrier, J., and Dixon, C., 2010, Distribution and movement of bull trout in the upper Jarbidge River watershed, Nevada: U.S. Geological Survey Open-File Report 2010-1033, 80 p., (Also available at http://pubs.usgs.gov/of/2010/1033/.)

DeHaan, P., and Godfrey, L., 2009, Genetic analysis of bull trout in the Jarbidge River watershed, Nevada/Idaho: report to the U.S. Fish and Wildlife Service, Reno, NV., 34 p., accessed April 12, 2011 at http://www.fws.gov/nevada/protected_species/fish/documents/bt/Final_Jarbidge_Bull_Trout_ Genetics_Report_1-5-09.pdf.

Homel, K., and Budy, P., 2008, Temporal and spatial variability in the migration patterns of juvenile and subadult bull trout in northeastern Oregon: Transactions of the American Fisheries Society, v. 137, p. 869-880.

Mogen, J.T., and Kaeding, L.R., 2005, Identification and characterization of migratory and nonmigratory bull trout populations in the St. Mary River drainage, Montana: Transactions of the American Fisheries Society, v. 134, p. 841-852. 


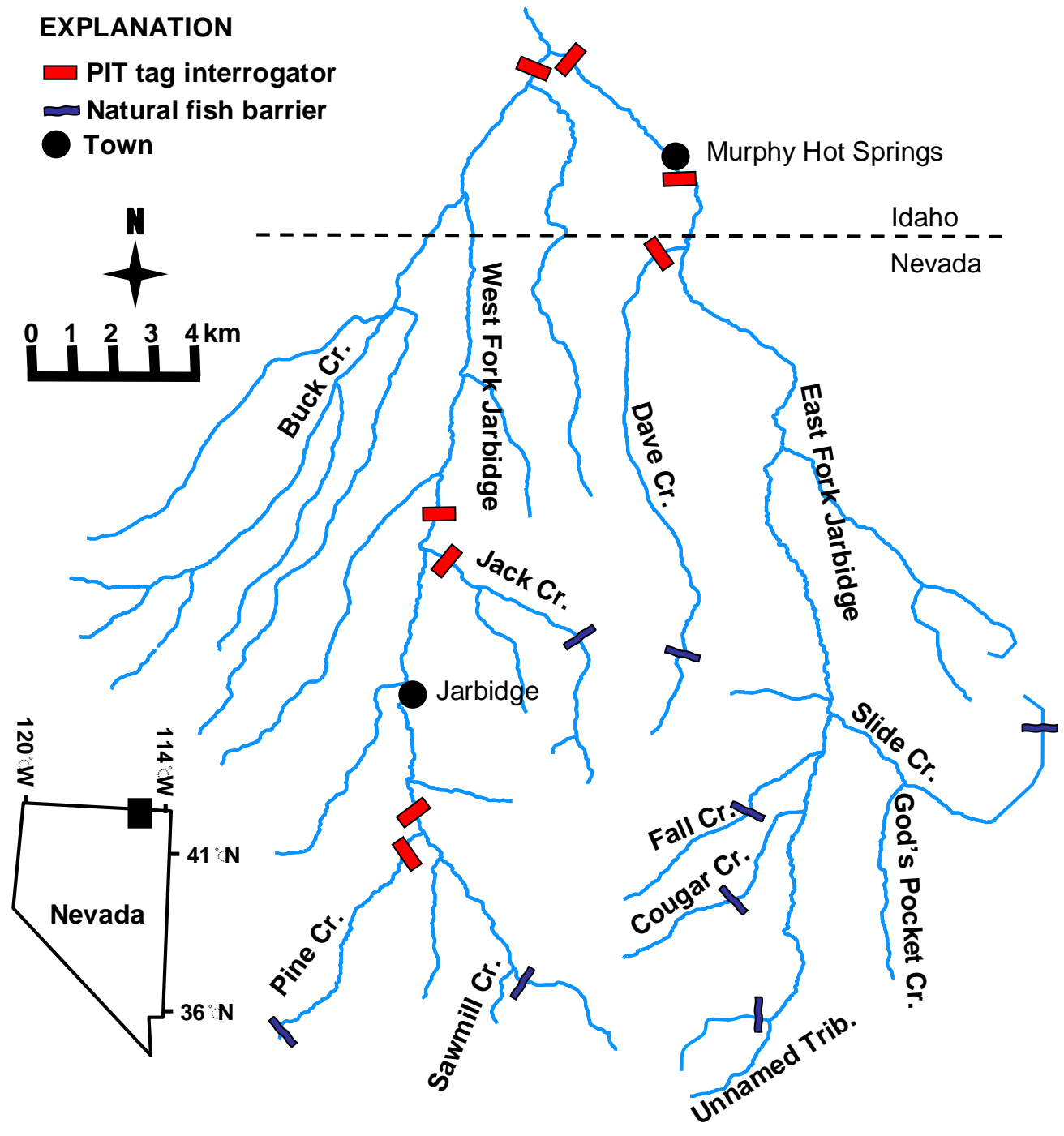

Figure 1. Map of the West and East Forks of the Jarbidge River, Idaho and Nevada, with the locations of reported fish passage barriers and passive integrated transponder (PIT) tag interrogation systems operating in 2008 and 2009. 


\section{EXPLANATION}

\section{8}

Flow (cfs)

Dave Cr. Temp

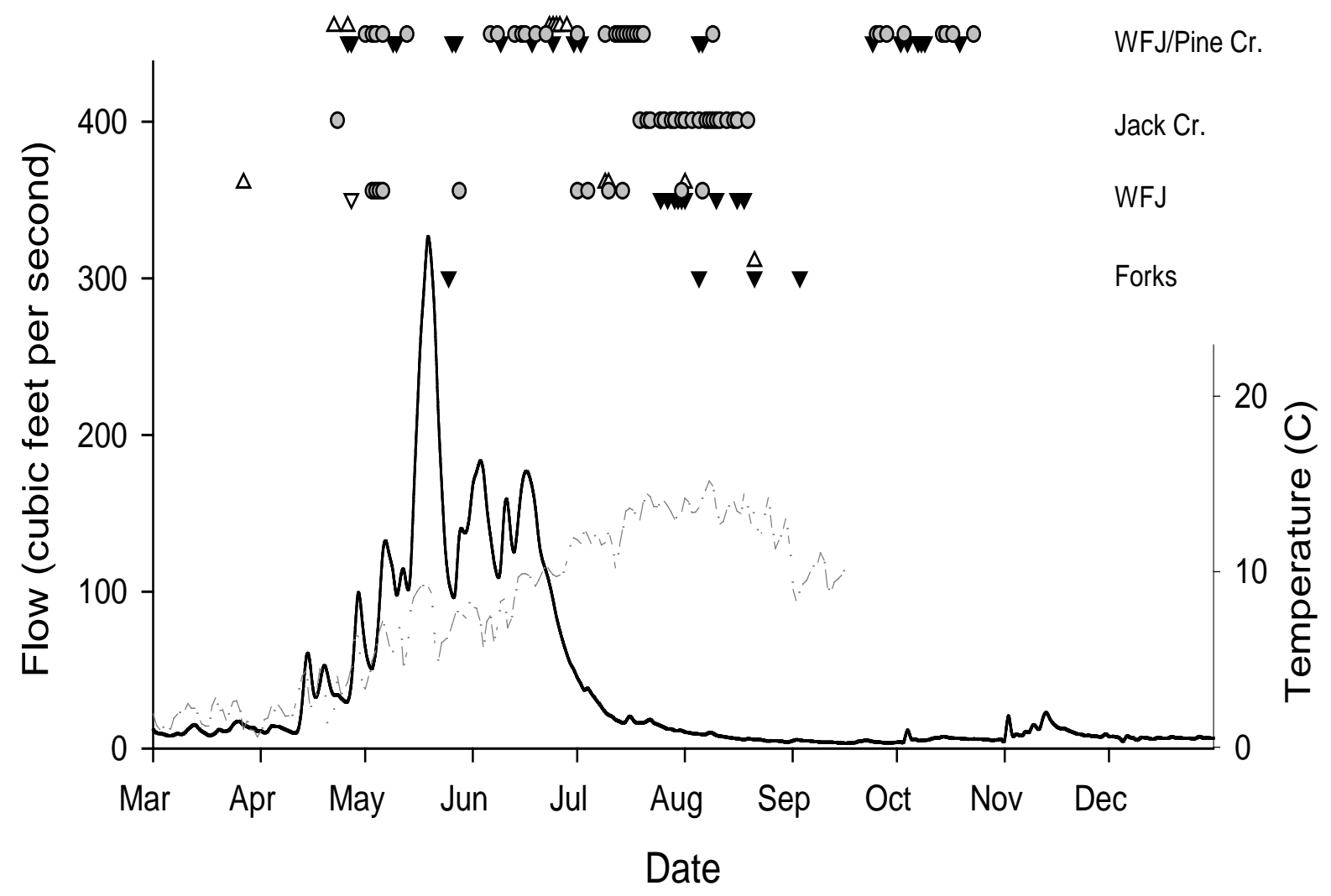

Figure 2. Flow, water temperature, and direction of PIT-tagged bull trout movements detected at PIT tag interrogation sites (PTISs) in East Fork Jarbidge River (EFJ, rkm 4.1), West Fork Jarbidge and Pine Creek confluence (rkm 26), Jack Creek (rkm 0.1), West Fork Jarbidge River (WFJ, rkm 15), and the Forks (rkm 0.1), Idaho and Nevada, 2008. PTISs were operated March 26-December 8. Triangles pointing up indicate upstream movement, inverse triangles indicate downstream movement, and circles indicate an unknown direction. Stream flow measurements were taken from the U.S. Geological Survey gaging station on the West Fork Jarbidge River (rkm 19.2). Water temperatures were from a thermologger at rkm 0.4 in Dave Creek maintained by the Bureau of Land Management. Data from other thermologgers were not available, owing to loss in high flows in 2008. 
EXPLANATION

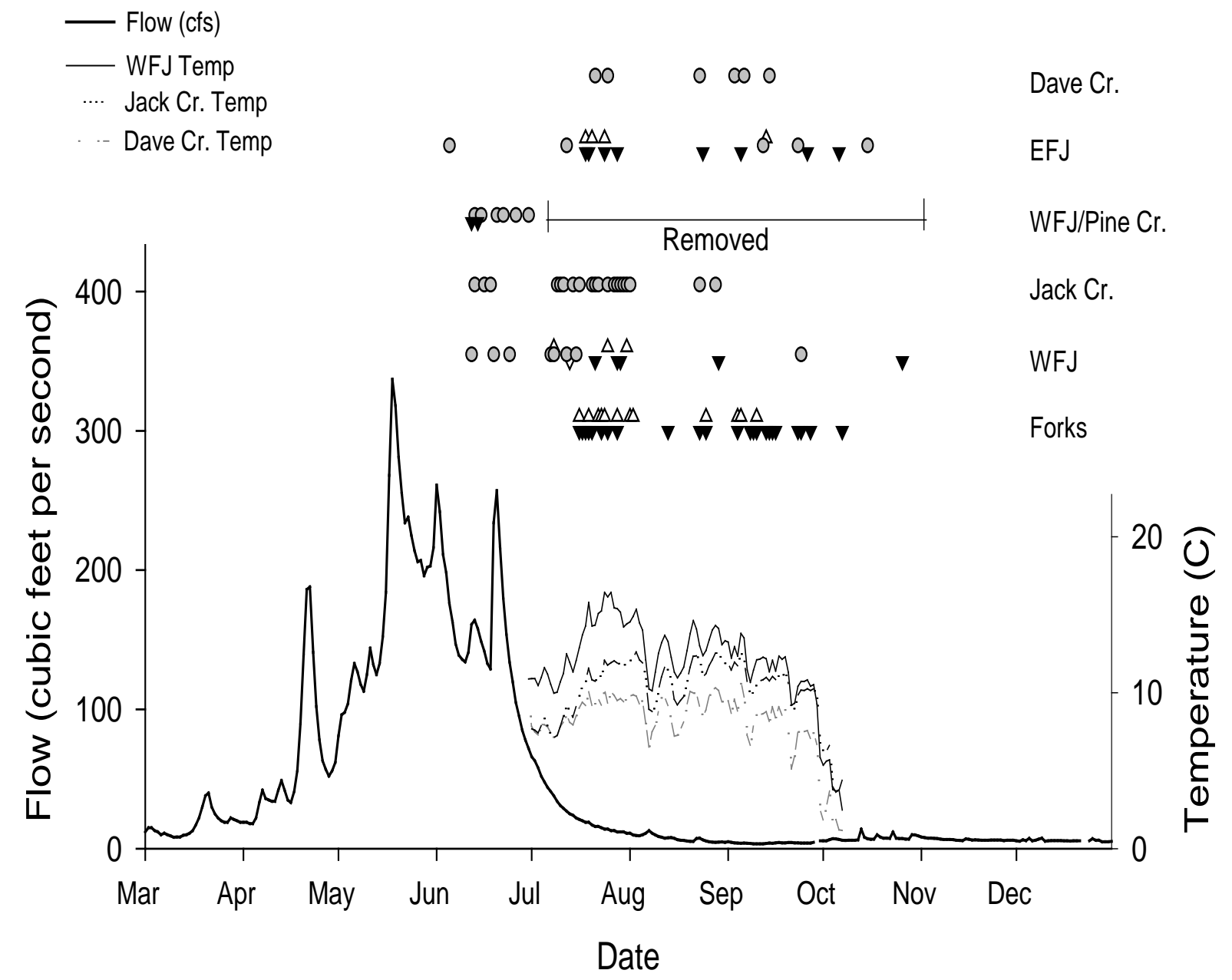

Figure 3. Flow, water temperature, and direction of PIT-tagged bull trout movements detected at PIT tag interrogation sites (PTISs) in Dave Creek (rkm 0.4), East Fork Jarbidge River (EFJ, rkm 4.1), West Fork Jarbidge and Pine Creek confluence (rkm 26), Jack Creek (rkm 0.1), West Fork Jarbidge River (WFJ, rkm 15), and the Forks (rkm 0.1), Idaho and Nevada, 2009. PTISs were operated April 7-December 2. Triangles indicate upstream movement, inverse triangles indicate downstream movement, and circles indicate an unknown direction. Stream flow measurements were taken from the U.S. Geological Survey gaging station on the West Fork Jarbidge River ( $r k m$ 19.2). Temperatures were from thermologgers at rkm 10 in Dave Creek, rkm 1.9 in Jack Creek, and rkm 21 in WFJ maintained by Nevada Department of Wildlife. 
Table 1. Number of PIT-tagged bull trout detected by tagging location, Idaho and Nevada, 2008-

09.

[Streams are listed in an upstream to downstream order within a watershed. WFJ, West Fork Jarbidge PIT tag interrogation system; EFJ, East Fork Jarbidge PIT tag interrogation system. The number in parentheses is the number of individual bull trout that also were detected in a previous year]

\begin{tabular}{|c|c|c|c|c|c|c|}
\hline \multirow[b]{3}{*}{$\begin{array}{l}\text { Watershed } \\
\text { PIT tag interrogation site }\end{array}$} & \multirow[b]{3}{*}{$\begin{array}{c}\text { River } \\
\text { kilometer }\end{array}$} & \multicolumn{5}{|c|}{ Number of bull trout detected by tagging location } \\
\hline & & \multicolumn{3}{|c|}{ West Fork Jarbidge } & \multicolumn{2}{|c|}{ East Fork Jarbidge } \\
\hline & & West Fork & $\begin{array}{l}\text { Pine } \\
\text { Creek }\end{array}$ & $\begin{array}{c}\text { Jack } \\
\text { Creek }\end{array}$ & $\begin{array}{l}\text { Dave } \\
\text { Creek }\end{array}$ & East Fork \\
\hline Number of bull trout tagged i & -07: & 352 & 405 & 167 & 222 & 337 \\
\hline \multicolumn{7}{|c|}{ West Fork Jarbidge River - 2008} \\
\hline WFJ at Pine Creek & 26.2 & 9 & 10 & 0 & 0 & 0 \\
\hline Pine Creek at WFJ & 0.1 & 10 & 18 & 1 & 0 & 0 \\
\hline Jack Creek & 0.1 & 1 & 9 & 5 & 0 & 0 \\
\hline $\begin{array}{l}\text { WFJ downstream of Jack } \\
\text { Creek }\end{array}$ & 15.0 & 3 & 9 & 6 & 1 & 0 \\
\hline WFJ at Forks & 0.1 & 1 & 1 & 0 & 0 & 0 \\
\hline \multicolumn{7}{|c|}{ West Fork Jarbidge River - 2009} \\
\hline WFJ at Pine Creek & 26.2 & 4 & 0 & 0 & 0 & 0 \\
\hline Pine Creek at WFJ & 0.1 & 2 & 0 & 0 & 0 & 0 \\
\hline Jack Creek & 0.1 & 2 & 9 & 1 & 0 & 0 \\
\hline $\begin{array}{l}\text { WFJ downstream of Jack } \\
\text { Creek }\end{array}$ & 15.0 & 5 & 9 & 0 & 0 & 0 \\
\hline WFJ at Forks & 0.1 & 5 & 9 & 0 & 0 & 0 \\
\hline \multicolumn{7}{|c|}{ East Fork Jarbidge River - 2008} \\
\hline Dave Creek & 0.4 & 0 & 0 & 0 & 0 & 0 \\
\hline EFJ at Murphy Hot Springs & 4.1 & 0 & 0 & 0 & 0 & 1 \\
\hline EFJ at Forks & 0.1 & 0 & 1 & 0 & 0 & 1 \\
\hline \multicolumn{7}{|c|}{ East Fork Jarbidge River - 2009} \\
\hline Dave Creek & 0.4 & 0 & 2 & 0 & 0 & 0 \\
\hline EFJ at Murphy Hot Springs & 4.1 & 3 & 7 & 1 & 0 & 1 \\
\hline EFJ at Forks & 0.1 & 3 & 7 & 1 & 0 & 0 \\
\hline \multicolumn{2}{|c|}{ Total number of fish detected in 2008} & $18(8)$ & $24(4)$ & $8(2)$ & $1(1)$ & $1(0)$ \\
\hline \multicolumn{2}{|c|}{ Total number of fish detected in 2009} & $15(5)$ & $19(4)$ & $2(1)$ & $\mathbf{0}(\mathbf{0})$ & $1(0)$ \\
\hline
\end{tabular}


Table 2. Total number of PIT-tagged bull trout detected by month in the Jarbidge River watershed, Idaho and Nevada, 2008.

[Individual bull trout may have been detected more than once. Streams are listed in an upstream to downstream order within a watershed. PTISs were operated from March 26 to December 8. Bull trout were not detected in November or December]

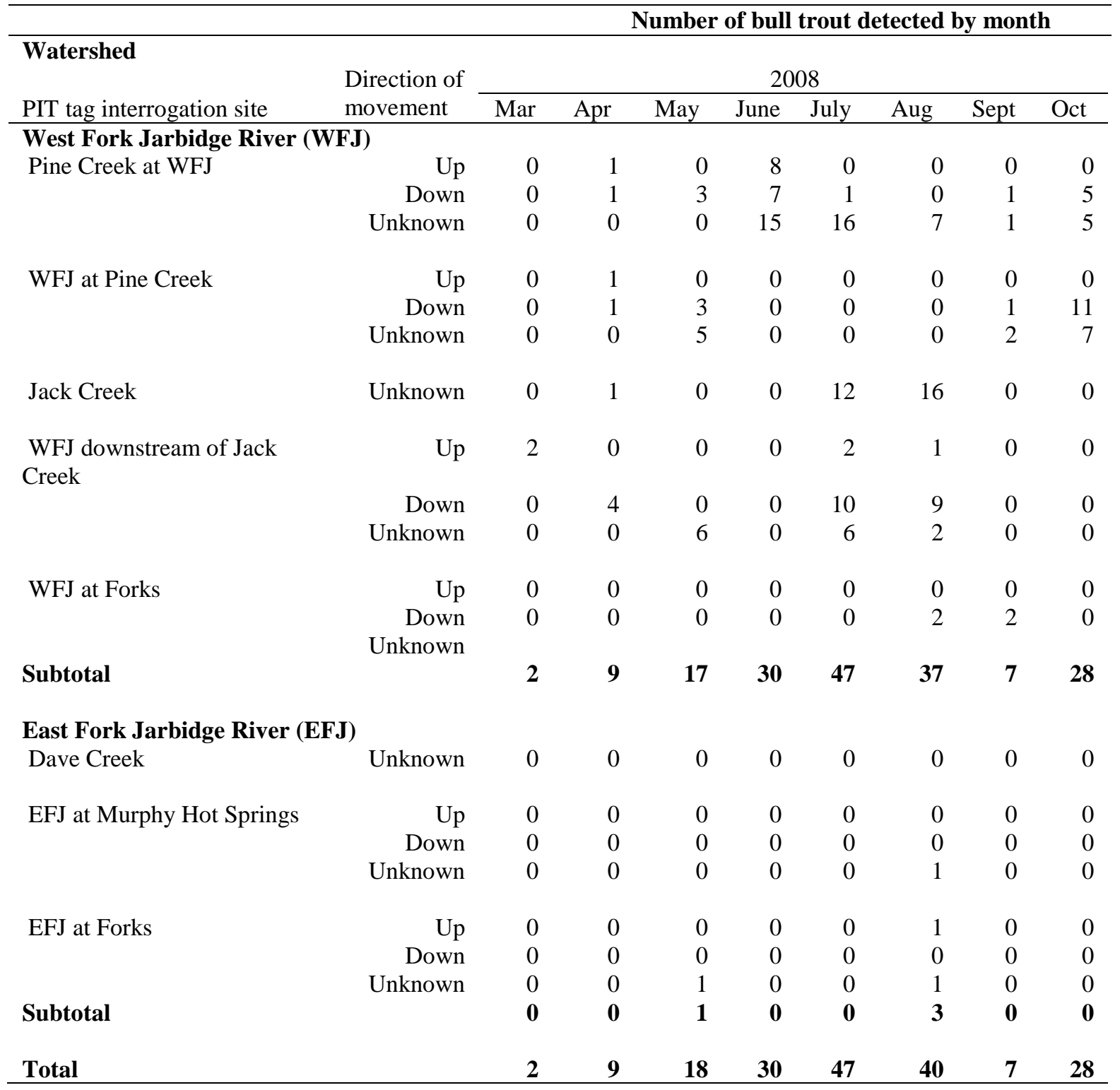


Table 3. Total number of PIT-tagged bull trout detected by month in the Jarbidge River watershed, Idaho and Nevada, 2009.

[Individual bull trout may have been detected more than once. Watersheds and streams are listed in an upstream to downstream order within a watershed. PTISs were operated from April 7 to December 2. Bull trout were not detected in November or December. The PTISs in Pine Creek were non-operational after July 1, 2009]

\begin{tabular}{|c|c|c|c|c|c|c|c|c|}
\hline \multirow{3}{*}{$\begin{array}{l}\text { Watershed } \\
\text { PIT tag interrogation site }\end{array}$} & \multirow{3}{*}{$\begin{array}{c}\text { Direction of } \\
\text { movement }\end{array}$} & \multicolumn{7}{|c|}{ Number of bull trout detected by month } \\
\hline & & \multicolumn{7}{|c|}{2009} \\
\hline & & Apr & May & June & July & Aug & Sept & Oct \\
\hline \multicolumn{9}{|c|}{ West Fork Jarbidge River (WFJ) } \\
\hline \multirow[t]{3}{*}{ Pine Creek at WFJ } & Up & 0 & 0 & 0 & --- & --- & --- & --- \\
\hline & Down & 0 & 0 & 1 & --- & --- & --- & --- \\
\hline & Unknown & 0 & 0 & 0 & --- & --- & --- & --- \\
\hline \multirow[t]{3}{*}{ WFJ at Pine Creek } & Up & 0 & 0 & 0 & --- & --- & --- & --- \\
\hline & Down & 0 & 0 & 1 & --- & --- & --- & --- \\
\hline & Unknown & 0 & 0 & 6 & --- & --- & --- & --- \\
\hline Jack Creek & Unknown & 0 & 0 & 3 & 18 & 3 & 0 & 0 \\
\hline \multirow{3}{*}{$\begin{array}{l}\text { WFJ downstream of Jack } \\
\text { Creek }\end{array}$} & Up & 0 & 0 & 0 & 6 & 0 & 0 & 0 \\
\hline & Down & 0 & 0 & 0 & 6 & 2 & 0 & 2 \\
\hline & Unknown & 0 & 0 & 3 & 5 & 0 & 1 & 0 \\
\hline \multirow[t]{3}{*}{ WFJ at Forks } & Up & 0 & 0 & 0 & 9 & 5 & 0 & 0 \\
\hline & Down & 0 & 0 & 0 & 10 & 2 & 10 & 0 \\
\hline & Unknown & 0 & 0 & 0 & 2 & 0 & 2 & 0 \\
\hline Subtotal & & $\mathbf{0}$ & $\mathbf{0}$ & 14 & 56 & 12 & 13 & 2 \\
\hline \multicolumn{9}{|c|}{ East Fork Jarbidge River (EFJ) } \\
\hline Dave Creek & Unknown & 0 & 0 & 0 & 2 & 1 & 1 & 0 \\
\hline \multirow[t]{3}{*}{ EFJ at Murphy Hot Springs } & Up & 0 & 0 & 0 & 6 & 0 & 2 & 0 \\
\hline & Down & 0 & 0 & 0 & 6 & 2 & 4 & 2 \\
\hline & Unknown & 0 & 0 & 1 & 3 & 0 & 2 & 1 \\
\hline \multirow[t]{3}{*}{ EFJ at Forks } & Up & 0 & 0 & 0 & 2 & 0 & 3 & 0 \\
\hline & Down & 0 & 0 & 0 & 1 & 1 & 4 & 0 \\
\hline & Unknown & 0 & 0 & 0 & 5 & 0 & 4 & 1 \\
\hline Subtotal & & $\mathbf{0}$ & $\mathbf{0}$ & 1 & 25 & 4 & 20 & 4 \\
\hline Total & & 0 & $\mathbf{0}$ & 15 & 81 & 16 & 33 & 6 \\
\hline
\end{tabular}


Publishing support provided by the U.S. Geological Survey

Publishing Network, Tacoma Publishing Service Center

For more information concerning the research in this report, contact the Director, Western Fisheries Research Center U.S. Geological Survey

6505 NE 65th Street

Seattle, Washington 98115

http://wfrc.usgs.gov/ 


\section{㞭}

